\title{
Article \\ Selective Laser Melting of Ti6A14V-2\%Hydroxyapatite Composites: Manufacturing Behavior and Microstructure Evolution
}

\author{
Hassanen Jaber ${ }^{1,2}$, János Kónya ${ }^{1,3}$ and Tünde Anna Kovács ${ }^{4, *}$ \\ 1 Doctoral School on Materials Sciences and Technologies, Óbuda University, 1034 Budapest, Hungary; \\ hassen.jaber@uni-obuda.hu (H.J.); janos@dentarttechnik.hu (J.K.) \\ 2 Biomedical Engineering Department, College of Engineering, University of Thi-Qar, Nasiriyah 64001, Iraq \\ 3 Dent-Art-Technik Kft. Magyarország, 9024 Győr, Hungary \\ 4 Donát Bánki Faculty of Mechanical and Safety Engineering, Óbuda University, 1081 Budapest, Hungary \\ * Correspondence: kovacs.tunde@uni-obuda.hu
}

check for

updates

Citation: Jaber, H.; Kónya, J.; Anna Kovács, T. Selective Laser Melting of Ti6Al4V-2\%Hydroxyapatite

Composites: Manufacturing Behavior and Microstructure Evolution. Metals 2021, 11, 1295. https://doi.org/ $10.3390 /$ met11081295

\section{Academic Editors:}

Christian Mittestedt, Bo Song and Jürgen Eckert

Received: 17 June 2021

Accepted: 11 August 2021

Published: 16 August 2021

Publisher's Note: MDPI stays neutral with regard to jurisdictional claims in published maps and institutional affiliations.

Copyright: (c) 2021 by the authors. Licensee MDPI, Basel, Switzerland. This article is an open access article distributed under the terms and conditions of the Creative Commons Attribution (CC BY) license (https:// creativecommons.org/licenses/by/ $4.0 /)$.

\begin{abstract}
In this work, selective laser melting of Ti6Al4V (Ti64) and 2 wt.\% hydroxyapatite (HA) composites was performed with the purpose of osseointegration enhancement and biological fixation between implants and bone tissue. The microstructural evolution and mechanical properties were analyzed by using X-ray diffraction (XRD), optical microscopy (OM), a scanning electron microscope (SEM) equipped with (EDX) and (EBSD) systems, microhardness, nanoindentation, and tensile testing. The results showed that the Ti64-2\%HA composite components exhibited complicated manufacturing behavior, which could be correlated with the decomposition of HA. The microstructure was found to mainly consist of $\alpha \mathrm{Ti}$ with a small amount of HA distributed along grain boundaries. Furthermore, the interaction between Ti64 and HA leading to the formation of $\mathrm{Ti}_{3} \mathrm{P}, \mathrm{Ti}_{\mathrm{x}} \mathrm{O}, \mathrm{P}$, and $\mathrm{CaTiO}_{3}$ phases, resulted in poor tensile properties, as compared to pure Ti64 components. Conversely, the tensile properties of SLM Ti64-2\%HA composite components were significantly higher than human bone reported previously in the literature.
\end{abstract}

Keywords: selective laser melting; Ti6A14V alloy; additive manufacturing; metal-ceramic composite; hydroxyapatite

\section{Introduction}

Selective laser melting (SLM) is a type of fusion additive manufacturing technology in which a laser beam is selectively scanned to melt a powder of materials (layer by layer) by an optics and scanner system [1]. Recently, there has been considerable interest in manufacturing knee, hip, ankle, maxillofacial, and spinal prostheses by SLM based on medical imaging instead of casting and forging [2,3]. This is due to features of SLM technology that produce lattice (scaffolds) or complex structures and functionally graded materials (FGM) [4].

Metallic alloys (stainless steel, CoCrMo, Ti-alloys) are biomaterials that are used in orthopedic bone, joint substitutions, and dental implants to interact with living tissue. Owing to their excellent biocompatibility, high relative strength, favorable osseointegration, and superior corrosion resistance, the Ti64 alloys play a crucial role in biomedical applications. Furthermore, Young's modulus of Ti64 alloys (105-110 GPa) is lower than that of the $316 \mathrm{~L}$ stainless steel (210 GPa) and cobalt-chromium alloys (230 GPa) [5]. Although there are many striking features of Ti64, there have also been several unresolved issues that remain regarding the resorption of the bone, the stability and fixation of Ti64 implants, and the inflammatory reaction of the body.

The resorption of the bone is a process of bone loss resulting from the large difference in Young's modulus between the bones (10-30 GPa) and the Ti64 implants (105-110 GPa) for patients under 40 years [6]. The significant difference in Young's modulus results in 
a non-gradual transfer of stress to the bone surrounding the implant, resulting in stress shielding and bone absorption. More details are given in our previous paper regarding this issue [4].

The stability and fixation of a Ti64 implant inside the bone and bone ingrowth at the interface are the greatest challenges after implantation [7]. There are several types of implant fixation: bone cement, mechanical fixation (screws), and activated surfaces of implants (coating) [8]. Bone cement is used in hip replacements to fix the bone stems, and to tackle the Young's modulus mismatch between the implant and the bone. The major limitation of bone cement is related to the potential cracks or infections occurring after implantation in the joint [9]. The coating of implants by the hydroxyapatite (HA) method represents an innovative alternative to the cemented fixation used previously [10]. Although implants coated with HA show good interfacial bonds between bone tissue and implants [11], there have been some issues regarding metal coating interface failure, to which there is still no accepted solution [12,13]. Another disadvantage of using Ti64 implants is that they allow for the release of metallic ions which can lead to an inflammatory reaction in the bone surrounding the implant [14].

This paper outlines a SLM of Ti64-HA as a composite powder to solve the most important Ti64 implant problems. HA was added in order to provide a solid biological fixation between the Ti64 implants and bone tissue without the use of bone cements. It is well known that the crystallographic and chemical composition of $\mathrm{HA}\left(\mathrm{Ca}_{10}\left(\mathrm{PO}_{4}\right)_{6}(\mathrm{OH})_{2}\right)$ is similar to that found in the bone tissue, which can dramatically enhance osseointegration and biological fixation. Moreover, other advantages of HA which could have decreased the inflammation reaction or allergic risks and accelerated the bonding are bioactivity, biocompatibility, non-inflammatory, non-toxicity, non-immunogenicity agent, and osteoconductivity [15].

Until recently, minimal research has been conducted on the SLM of Ti-HA composites. Han et al. [16] investigated the microstructure and mechanical properties of SLMprocessed pure titanium (CP Ti)-HA composites. Marcu et al. [17] studied the effect of SLM variables on the microstructure evolution and mechanical properties of Ti6Al7Nb-HA composites. Therefore, the present paper aims to study the phases, microstructure, and mechanical properties of Ti64-2\%HA composite samples manufactured by SLM. Moreover, the microstructure and mechanical properties of Ti64-2\%HA were compared with pure SLM-fabricated Ti64.

\section{Materials and Methods}

\subsection{Materials Preparation}

In this work, 2 wt.\% HA powder (nanoXIM HA203, Fluidinova, Mala, Portugal) was added into the Ti64 powder (Gr.23, LPW Technology Ltd., Runcorn, UK) followed by mechanical mixing and the SLM process. The Ti64 gas atomized spherical powder (Figure 1A) had a nominal particle size ranging from 15 to $45 \mu \mathrm{m}$. Figure 1B shows an SEM micrograph for the mixture of the Ti64 and HA powders and their diameter distributions. Table 1 presents the chemical composition of the investigated Ti64 powder and ASTM specification (ASTM B348 Gr.23). Figure 1C shows the chemical compositions of HA. The hydroxyapatite powder had an average particle size $\mathrm{d}_{50}$ of $10 \mu \mathrm{m}$ and specific surface area $\geq 100 \mathrm{~m}^{2} / \mathrm{g}$. Mechanical mixing to produce the Ti64-2\%HA composite was performed using a planetary ball milling apparatus. The mixing time was $8 \mathrm{~h}$. 

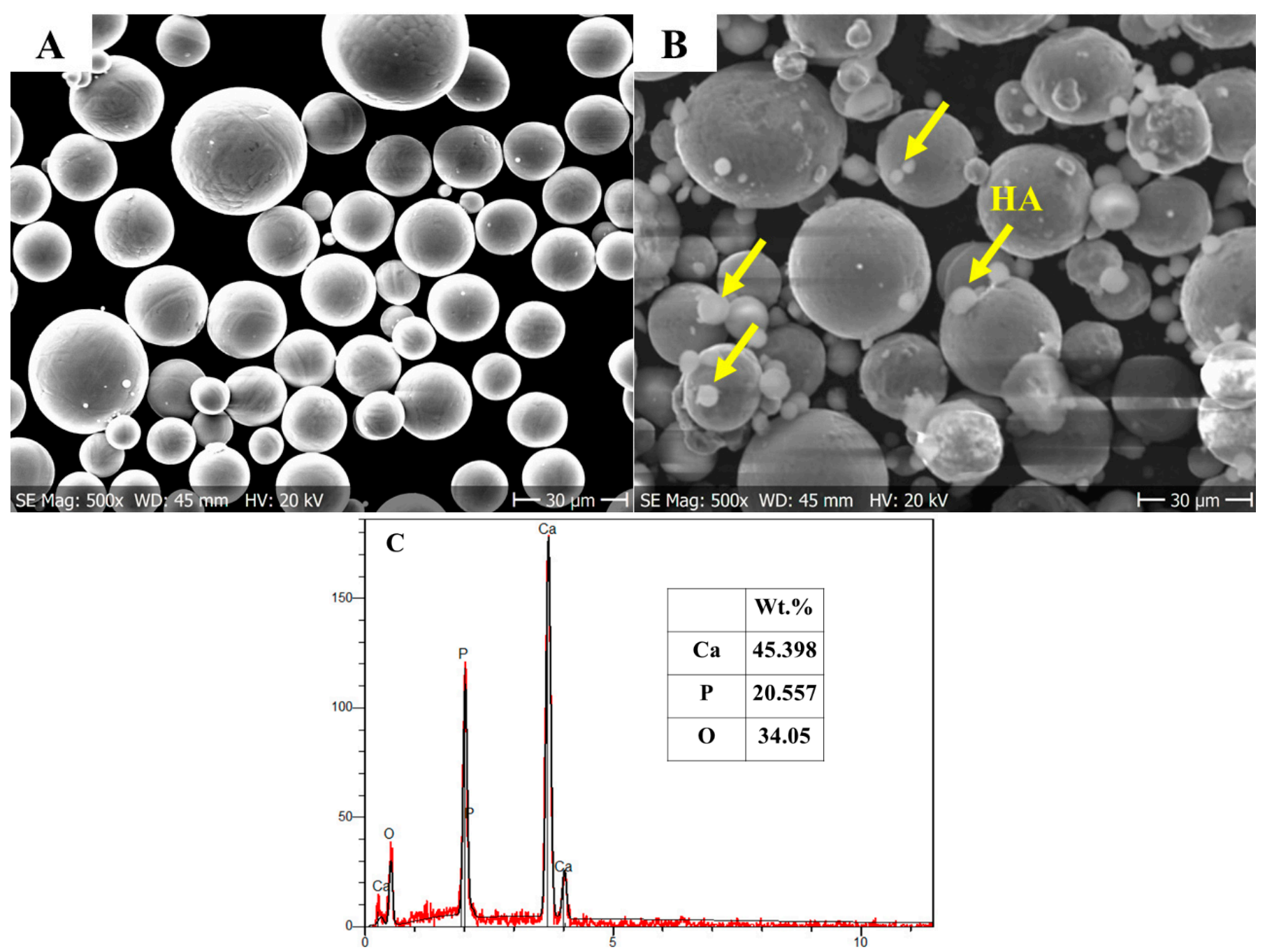

Figure 1. Morphology of the powders: (A) SEM micrograph of pure Ti64 powder; (B) SEM micrograph Ti64 powder mixed with 2 wt.\% of HA powder; (C) Chemical compositions (wt.\%) of HA.

Table 1. Chemical analysis of Ti64 powder and ASTM specification.

\begin{tabular}{cccccccccc}
\hline (Mass\%) & & AL & V & Fe & O & N & C & H & Ti \\
\hline Ti6Al4V powder & 6.11 & 4.02 & 0.17 & 0.090 & 0.023 & 0.01 & 0.003 & Bal \\
\hline \multirow{2}{*}{ ASTM B348 Gr.23 } & Max & 6.50 & 4.50 & 0.25 & 0.13 & 0.03 & 0.08 & 0.0125 & Bal \\
\cline { 2 - 10 } & Min & 5.50 & 3.50 & - & - & - & - & - & - \\
\hline
\end{tabular}

\subsection{SLM System and Processing}

SLM was conducted using a commercial SLM (Sisma MYSINT 100, Via dell'Industria, Vicenza, Italia) system with a $200 \mathrm{~W}$ laser fiber and a $55 \mu \mathrm{m}$ laser spot. Laser power, scanning speed, and layer thickness were kept constant (optimum conditions) at $125 \mathrm{~W}$, $1000 \mathrm{~mm} / \mathrm{s}$, and $20 \mu \mathrm{m}$, respectively. Parameters of SLM were selected based on a guideline available with a Sisma MYSINT 100 machine and trial and error tests. Pure argon gas was used to shield at a flow rate of $35 \mathrm{~L} / \mathrm{min}$.

The tensile test was conducted to investigate the mechanical performance of the printed samples. Mechanical performance of the printed samples was described in terms of yield and ultimate tensile strength and the total elongation. The sample dimensions were as described by ASTM E8. Figure 2 details the dimensions of the tensile specimen. The tensile test was conducted by using a non-computerized testing machine (FORM + TEST, 
Model: TTM 100, Zwiefalter Straße, Germany) at a crosshead speed of $1 \mathrm{~mm} / \mathrm{min}$. An average of three tests was performed for each tensile testing.

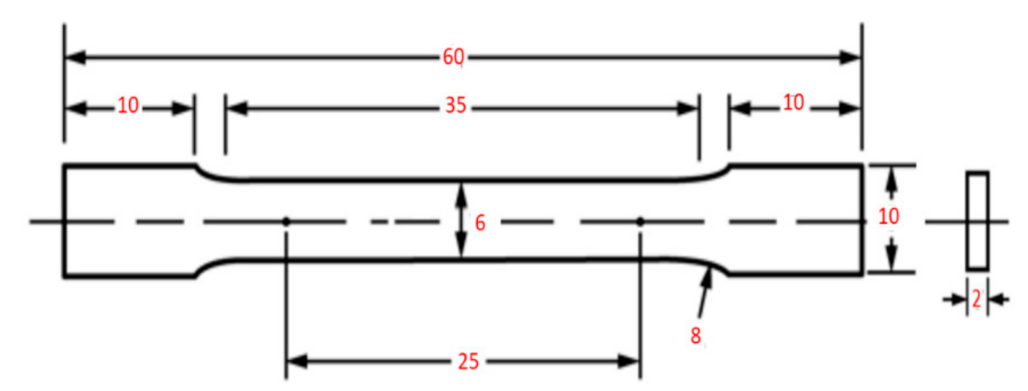

Figure 2. The shape and size of the tensile sample (mm).

\subsection{Materials Characterization}

Samples for metallographic examination through the cross section were prepared using the standard metallography procedure, and Keller's reagent $\left(92 \mathrm{~mL} \mathrm{H}_{2} \mathrm{O}, 6 \mathrm{~mL}\right.$ $\mathrm{HNO}_{3}$, and $2 \mathrm{~mL} \mathrm{HF}$ ) was used to reveal the microstructure. X-ray diffraction (XRD) with $\mathrm{Cu}-\mathrm{K} \alpha$ radiation and the wavelength of $\lambda=1.5406 \AA$ at $40 \mathrm{kV}$ and $30 \mathrm{~mA}$ was used to determine the phase constituent of the microstructures of the printed samples. To investigate the microstructural evolution, optical microscopy (OM, Neophot 2, Carl Zeiss, Jena, Germany) and FEI Quanta 3D scanning electron microscope (SEM, Hitachi, Tokyo, Japan) equipped with an EDS were utilized. The EDS spot examinations were carried out to describe the chemical composition of the phases. To examine the chemical composition profile across the grain boundaries and phases, the EDS line scan analysis was performed. EDS mapping analysis allowed for the distribution of the $\mathrm{HA}(\mathrm{Ca}, \mathrm{O}$ and $P$ spectra) precipitates on the Ti64 matrix to be characterized. In order to understand the relationship between the microstructure and mechanical properties, Vickers microhardness testing was conducted with a dwell time of $10 \mathrm{~s}$ and a load of $0.5 \mathrm{~kg}$ f.3. Furthermore, micro/nanoindentation testing was performed with an applied load of $3500 \mathrm{mN}$ and holding time of $10 \mathrm{~s}$.

\section{Results and Discussion}

\subsection{Material Behavior during the SLM Process of Ti64-HA Composites}

The Ti64 powder was blended with different weight ratios of HA, including 2, 3, 4 , and $5 \mathrm{wt} . \%$. The Ti64 -HA composite materials, especially at high amounts of HA, showed a complicated production behavior; during SLM processing there were several explosions (popups) which led to a crash of the support structure. Figure 3 illustrates this problem clearly. To our knowledge, some trapped water in the mesoporous structure of the HA powder or decomposition of $\mathrm{HA}$ may generate $\mathrm{H}_{2} \mathrm{O}$ gases, which may be responsible for these explosions. It has been found $[18,19]$ that at high temperatures above $1300^{\circ} \mathrm{C}$, the $\mathrm{HA}$ $\left[\mathrm{Ca}_{10}\left(\mathrm{PO}_{4}\right)_{6}(\mathrm{OH})_{2}\right]$ dissociates into $\mathrm{H}_{2} \mathrm{O}$ (gas) and Tetracalcium phosphate $\left[\mathrm{Ca}_{4}\left(\mathrm{PO}_{4}\right)_{2} \mathrm{O}\right]$ and/or tricalcium phosphate $\left[\mathrm{Ca}_{3}\left(\mathrm{PO}_{4}\right)_{2}\right]$. 


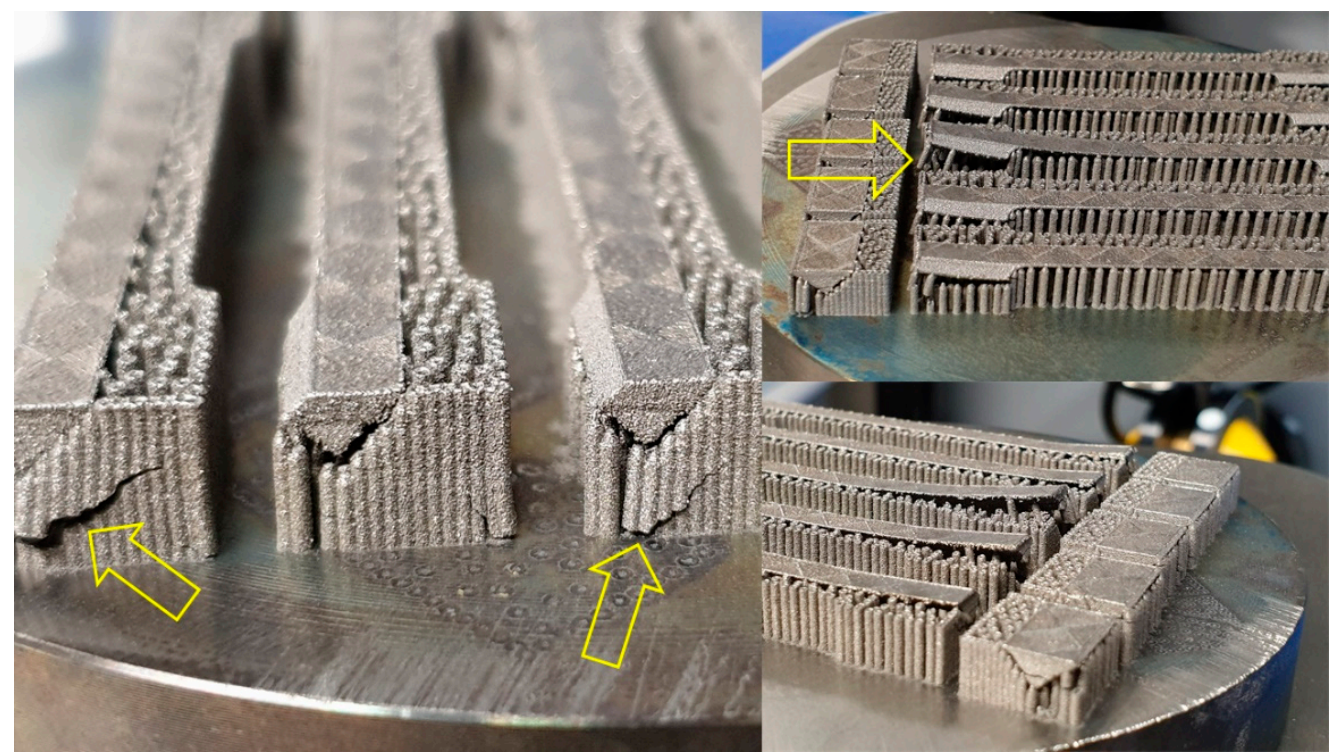

Figure 3. The crash of the support structure during SLM of Ti64-2\%HA composite.

In order to remove the effect of trapped/generated water and to reduce the effect of this "gas/explosion" problem on the SLM-fabricated Ti64-2\%HA, a preheated treatment of HA powder was required. Therefore, the temperature of HA powder was increased to $1000{ }^{\circ} \mathrm{C}$ for $2 \mathrm{~h}$ and the heating and cooling rate were $10{ }^{\circ} \mathrm{C} / \mathrm{min}$. After the heat treatment was performed, the HA powder was characterized by Fourier transform infrared spectroscopy (FTIR, PG Instruments, Leicester, UK) and X-ray diffraction (XRD, Panalytical Empyrean, Worcestershire, UK). The FTIR spectra (Figure 4) confirmed the stability of $\mathrm{HA}$ by the existence of peaks regarding phosphate $\left[\left(\mathrm{PO}_{4}\right)^{3-}\right.$ and $\left.\mathrm{PO}_{4}\right], \mathrm{OH}^{-}$, and $\mathrm{HPO}_{4}$ groups, which are of considerable significance in molecules of HA. XRD analysis (Figure 5) confirmed that the material was HA according to its (ICDD 00-024-0033) pattern.

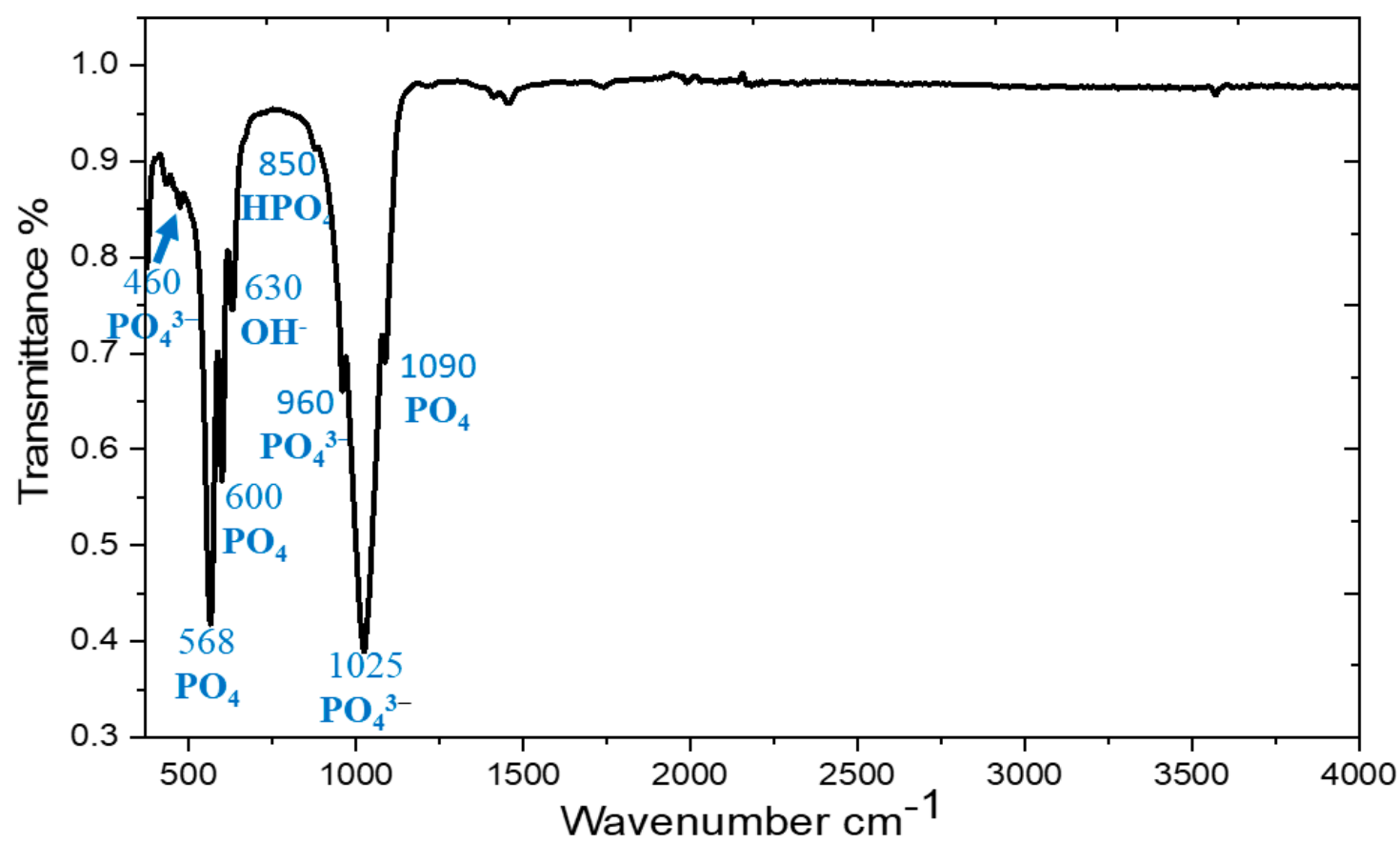

Figure 4. FTIR spectra of HA powder at a temperature of $1000^{\circ} \mathrm{C}$. 


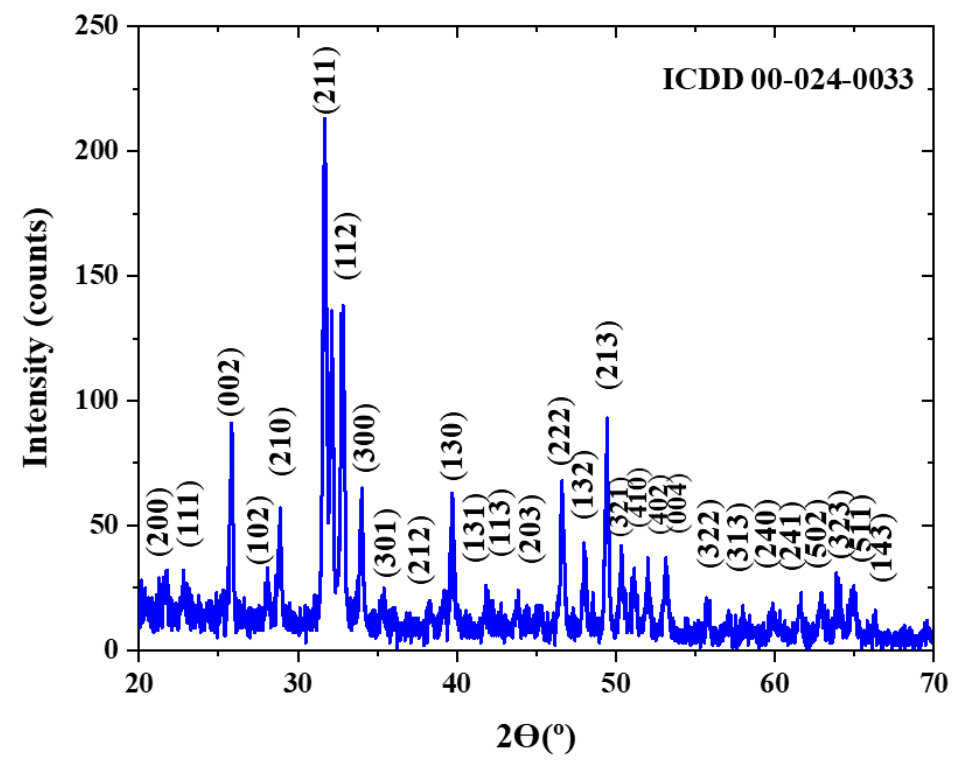

Figure 5. X-ray diffraction pattern of HA powder at a temperature of $1000^{\circ} \mathrm{C}$.

\subsection{Phase Structure Evolution}

The results of OM and SEM for the Ti64 samples and Ti64-2\%HA composites are compared in Figure 6. Figure 6A,B show typical OM and SEM micrographs of the Ti64 samples indicating a lath microstructure, consisting mainly of an $\alpha^{\prime}$ martensitic structure and a small amount of $\beta$-titanium ( $\beta$-Ti) at the grain boundaries. The analysis of XRD (Figure 7A) confirmed findings from the SEM and the formation of $\alpha^{\prime}$ martensite due to the appearance of hexagonal, close-packed (hcp) peaks, related to a martensitic structure. Figure 6C,D show typical OM and SEM micrographs of the Ti64-2\%HA composite showing the existence of small grain structures coupled with dark grain boundaries and some light green areas. The phases that formed during solidification of the Ti64-2\%HA composite were examined by XRD, EDS-line, EDS-spot and EDS-map.

Figure 7B presents the XRD pattern of the Ti64-2\%HA composites in which reflections of $\alpha \mathrm{Ti}$ (hcp) and HA phases are revealed. The HA structure is indicated at the peak of $2 \theta=57.2^{\circ}$ which represents the (322) diffraction planes according to (ICDD 00-024-0033). This peak is approximately the same as the peak previously revealed by Terrazas et al. [20]. Some phase identifications of Ti64-2\%HA composites can be difficult due to a high concentration of $\mathrm{Ti}$, which leads to strong diffraction peaks and, in turn, overshadow the peaks of the other phases which result from the decomposition of HA or interaction of Ti64-HA. Therefore, it appears that the XRD identified other phases such as $\mathrm{Ti}_{3} \mathrm{P}$, different titanium oxides $\mathrm{Ti}_{\mathrm{x}} \mathrm{O}\left(\mathrm{Ti}_{3} \mathrm{O}\right.$ and $\left.\mathrm{Ti}_{2} \mathrm{O}\right)$, and $\mathrm{CaTiO}_{3}$. According to the Ti-P phase diagram [21], a $\mathrm{P}$ weight fraction of 18 can form the $\mathrm{Ti}_{3} \mathrm{P}$ phase. Concomitantly, the mixing enthalpies of Ti-P, $\mathrm{Ti}-\mathrm{Al}$, and Ti-V were $-100.5,-30$, and $-4 \mathrm{~kJ} / \mathrm{mol}$, respectively [22]. Therefore, the $\mathrm{P}$ in HA could be reacting with the Ti in Ti64 to form the $\mathrm{Ti}_{3} \mathrm{P}$ phase during the SLM. According to the Ti-O binary phase diagram [21], it can be derived that $\mathrm{O}$ weight fractions of 8 and 18, $\mathrm{Ti}_{3} \mathrm{O}, \mathrm{Ti}_{2} \mathrm{O}$, and $\mathrm{Ti}_{3} \mathrm{O}_{2}$ can form in the structure. 


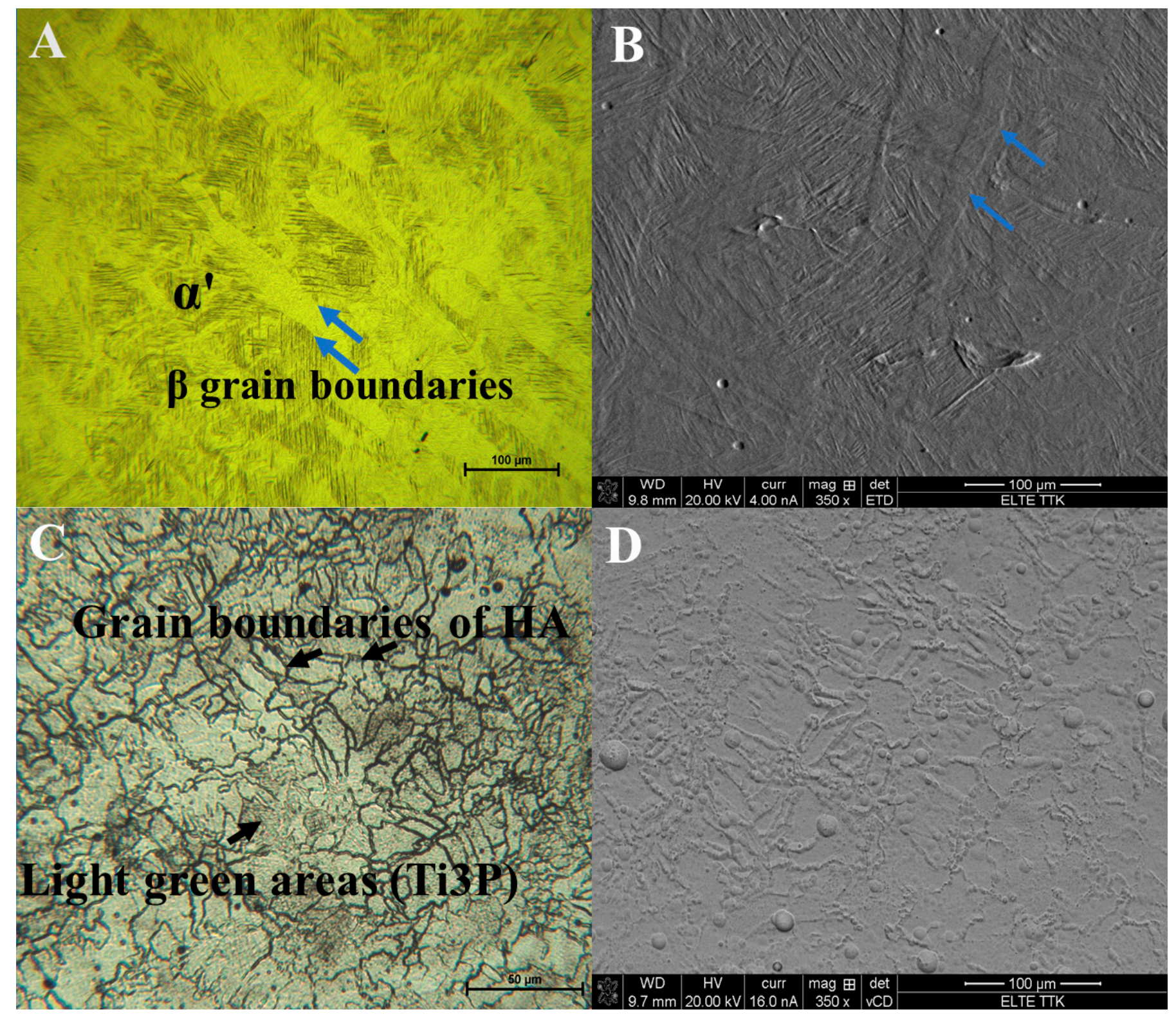

Figure 6. (A) Optical image and (B) SEM image showing microstructure of the Ti64 manufactured by SLM consists of $\alpha^{\prime}$ martensite and $\beta$ phase at the grain boundaries. (C) Optical image and (D) SEM image showing microstructure of the Ti64-2\%HA composite manufactured by SLM.

EDS mapping of the selected area (Figure 8) indicated a homogeneous distribution of $\mathrm{Ti}, \mathrm{V}$, and $\mathrm{O}$, whereas the other elements of $\mathrm{P}$, and $\mathrm{Ca}$ were assumed to be non-homogeneous. It was revealed that there were no significant overlaps between $\mathrm{Ca}, \mathrm{P}$, and $\mathrm{O}$ in select zones as illustrated in Figure 8 (white circles). On combining this result with the XRD, we conclude that the HA powders partially decomposed and interacted with the Ti which will be transformed into $\mathrm{Ti}_{3} \mathrm{P}, \mathrm{Ti}_{x} \mathrm{O}$, and $\mathrm{CaTiO}_{3}$ phases. Moreover, the intensity of the XRD peaks for the Ti64-2\%HA were significantly higher than Ti64. The decomposition of a certain percentage of HA has been reported in selective laser sintering of the NiTi-HA system [23]. 


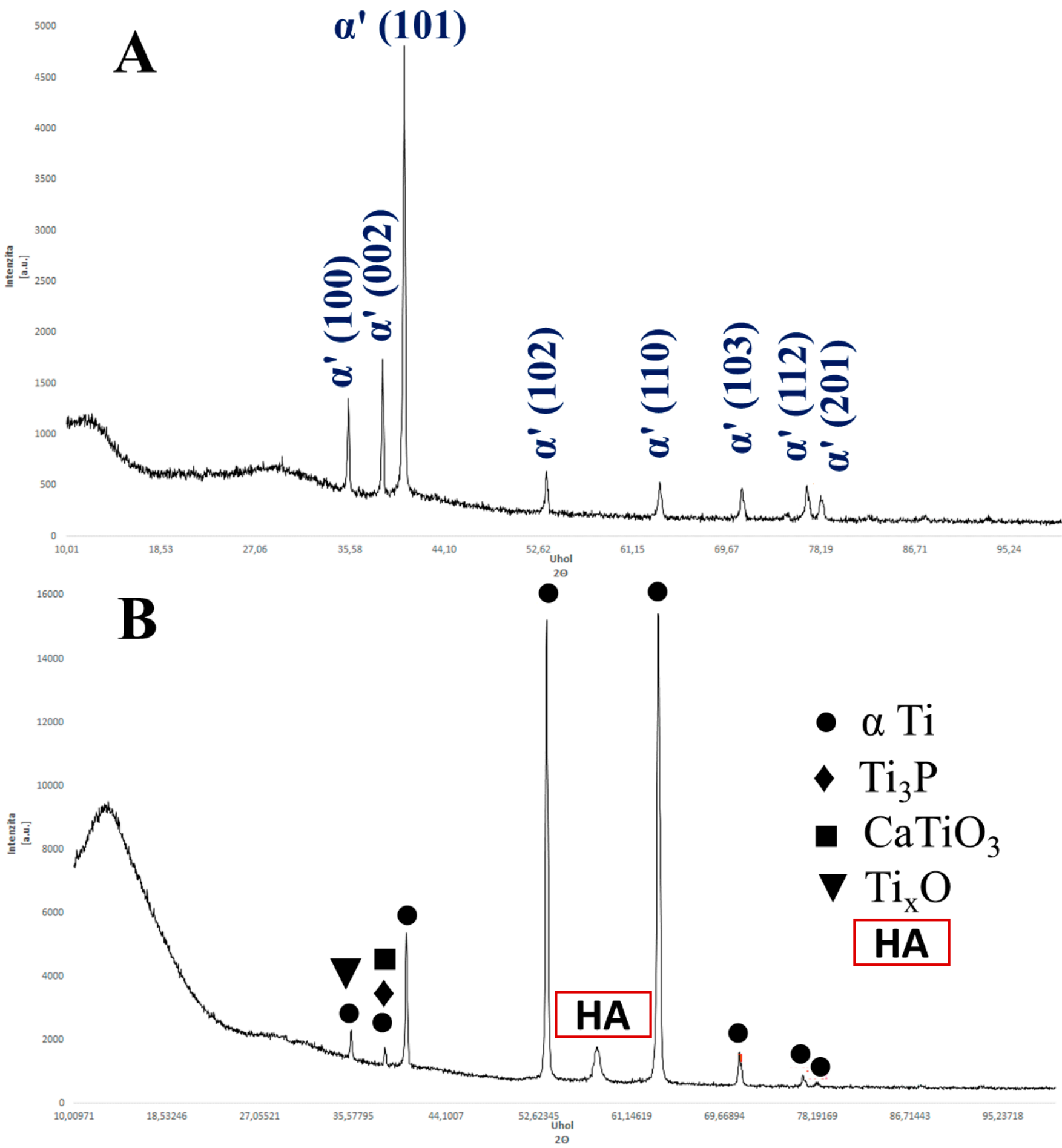

Figure 7. (A) The X-ray diffraction of the SLM of Ti64 indexing $\alpha^{\prime}$ martensitic structure. (B) The X-ray diffraction of the SLM of Ti64-2\%HA indexing $\alpha \mathrm{Ti}, \mathrm{HA}, \mathrm{Ti}_{3} \mathrm{P}, \mathrm{CaTiO}_{3}$, and $\mathrm{Ti}_{x} \mathrm{O}$ phases. 

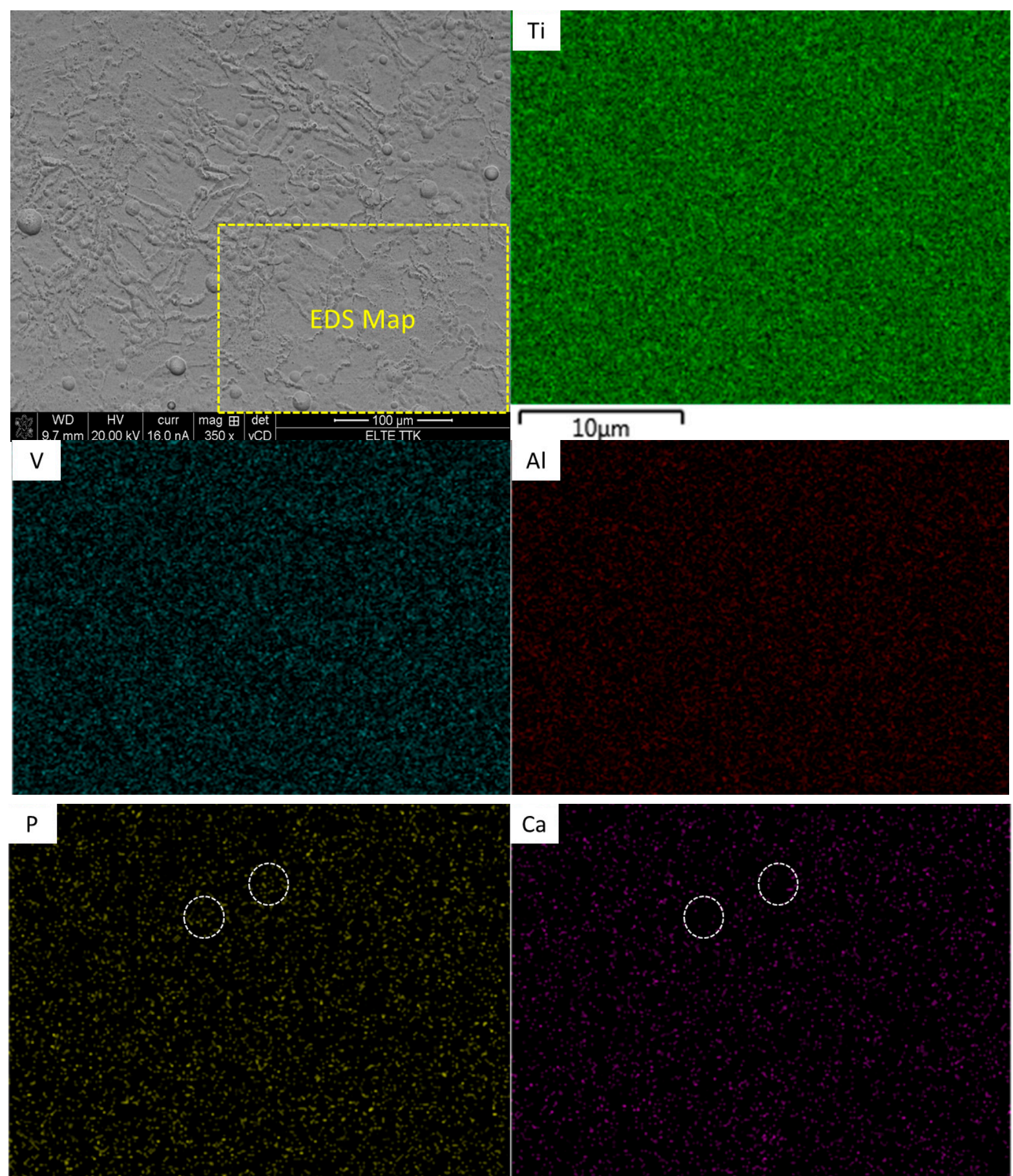

$\mathrm{Ca}$

0

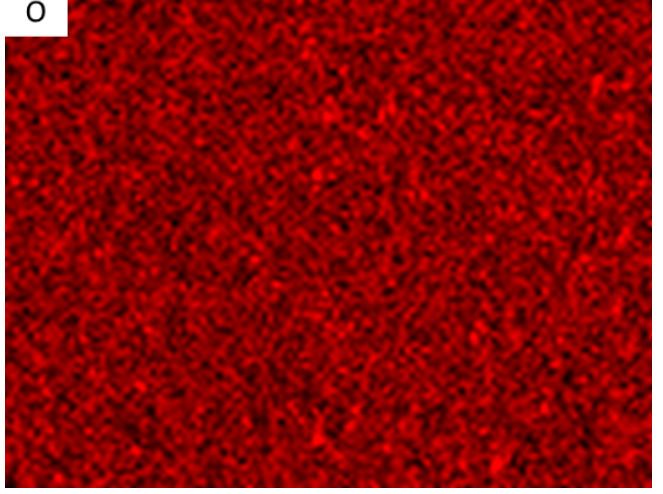

Figure 8. EDS mapping analysis of SLM Ti64-2\%HA composites. 
Figure 9 reveals an EDS line scan across the grain boundaries and inside grain domains in the structure, indicating the partitioning tendencies of Ti and $\mathrm{O}$ elements that are present in the grain boundaries when compared to that of the inside grain domains. As detailed in Figure 9, the phase formed in the grain boundaries was significantly enriched with $\mathrm{O}$. The quite low and high concentration of the $\mathrm{O}$ element in the discrete peaks of $\mathrm{O}$ could be attributed to the formation of $\mathrm{HA}$ and $\mathrm{Ti}_{\mathrm{x}} \mathrm{O}$. Another possible explanation for the formation of $\mathrm{Ti}_{\mathrm{x}} \mathrm{O}$ is that the $\mathrm{O}$ element content was relatively high, and this may have led to some amount of $\mathrm{Ti}_{\mathrm{x}} \mathrm{O}$ also forming in the microstructure after solidification.

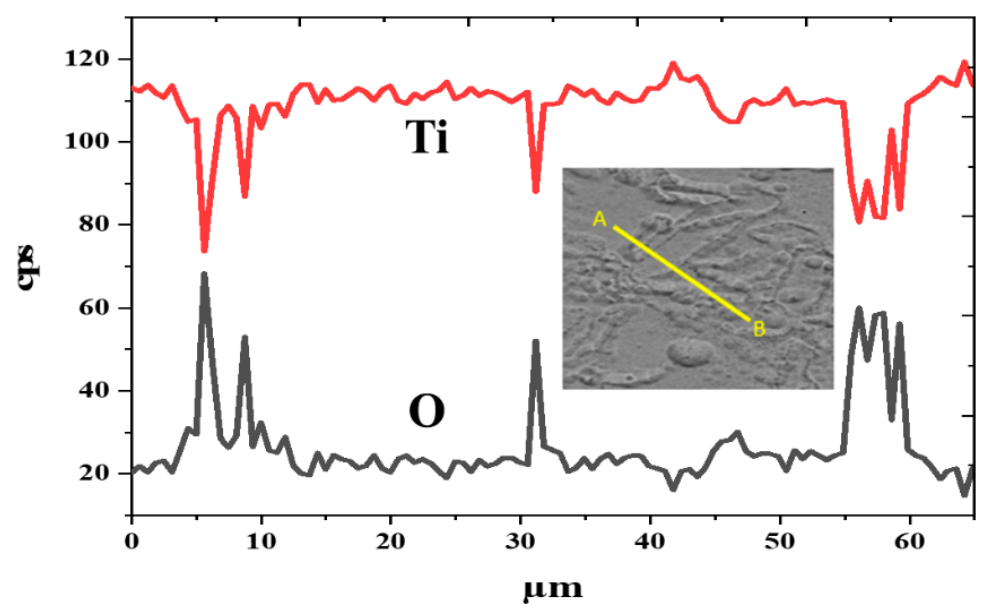

Figure 9. EDS line scan across the grain boundaries in structure of SLM Ti64-2\%HA composites.

The EDS-spot analysis (Table 2) revealed that grain boundaries had small amounts of $\mathrm{Ca}$ and $\mathrm{P}$, suggesting that $\mathrm{HA}$ was formed in the grain boundaries. The high tendency for precipitation of $\mathrm{HA}(\mathrm{Ca}, \mathrm{P}$ and $\mathrm{O})$ in grain boundaries could be attributed to the low melting point of $\mathrm{Ca}, \mathrm{P}$, and $\mathrm{O}$ elements. A small amount of $\mathrm{Ca}$ and $\mathrm{P}$ can be explained by the partially missing element during the standard metallography procedure. It has been shown that nonmetallic elements $(\mathrm{Ca}$ and $\mathrm{P}$ ) can easily be removed during grinding and polishing [24]. In addition, the EDS-spot analysis of the selected B and C points (Table 2) revealed that these points are enriched in phosphorus, suggesting that $\mathrm{Ti}_{3} \mathrm{P}$ is formed in these points. Interestingly, we noted that some spherical white nanosized particles were found to be dispersed on the microstructure of the Ti64-2\%HA composite at high magnification as shown in Figure 10. The white nanosized particles could be interpreted as being a result of $\mathrm{P}$ diffusion due to their small atomic radius which causes a high diffusion of $\mathrm{P}$ into the Ti64 matrix during the SLM.

Table 2. EDS spot analysis of grain boundary (GB) and inside grain domains in the structure of SLM Ti64-2\%HA composites.

\begin{tabular}{|c|c|c|c|c|c|c|c|}
\hline & \multirow{2}{*}{$\begin{array}{c}\text { Analysis } \\
\text { Points }\end{array}$} & \multicolumn{6}{|c|}{ Element wt.\% } \\
\hline & & Ti & Al & $\mathbf{V}$ & $\mathbf{O}$ & $\mathbf{P}$ & $\mathrm{Ca}$ \\
\hline & A & 83.61 & 4.36 & 2.58 & 8.36 & 1 & 0.09 \\
\hline & B & 86.28 & 7.75 & 2.57 & 3.2 & 0.20 & - \\
\hline 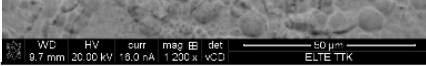 & $\mathrm{C}$ & 85.94 & 7.44 & 2.55 & 3.8 & 0.27 & - \\
\hline
\end{tabular}




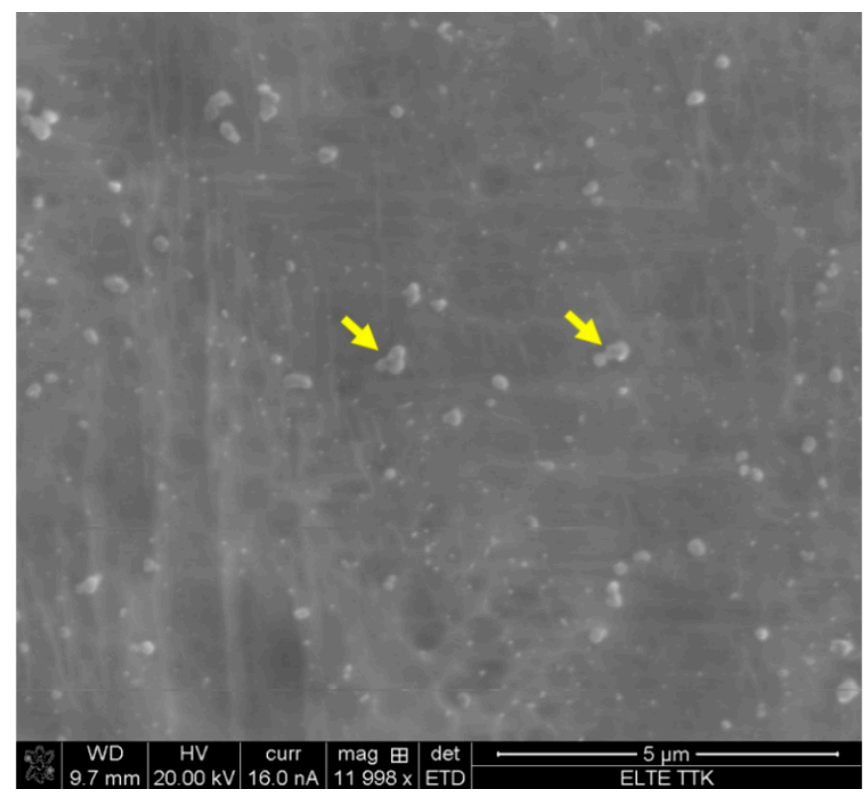

Figure 10. Nanosized particles on the microstructure of the SLM Ti64-2\%HA composites.

To additionally investigate and reveal the phases in SLM of the Ti64-2\%HA composite, a Vickers microhardness assessment was performed, and the results are illustrated in Figure 11. The average hardness of the Ti64 is $\sim 374 \mathrm{HV}$, which is in good agreement with its predominantly $\alpha^{\prime}$ martensitic structure. The hardness of the Ti64-2\%HA, averaged at $478 \mathrm{HV}$, is higher than the hardness of the Ti64. This increase in hardness can be explained by the presence of $\mathrm{HA}$ at grain boundaries and by the presence of $\mathrm{Ca}, \mathrm{P}$, and $\mathrm{O}$ elements due to the partial decomposition of HA. This results in the structure strengthening via a solid solution mechanism. Another potential explanation for an increase in hardness is the generation of the fine $\alpha$ Ti phase in the Ti64-HA structure. It has been shown that the fine $\alpha$ Ti phase is harder than the $\alpha^{\prime}$ martensite phase $[25,26]$. The heterogeneous hardness profile of Ti64-2\%HA compared to that of Ti64 is a result of different phases forming in the structure of the Ti64-2\%HA composite. The higher value of the hardness in the region (563 HV) as compared to the vicinity zones $(470 \mathrm{HV})$ can be attributed to the formation of the HA phase. It has been reported that the hardness of the HA phase is approximately $600 \mathrm{HV}$ [27].

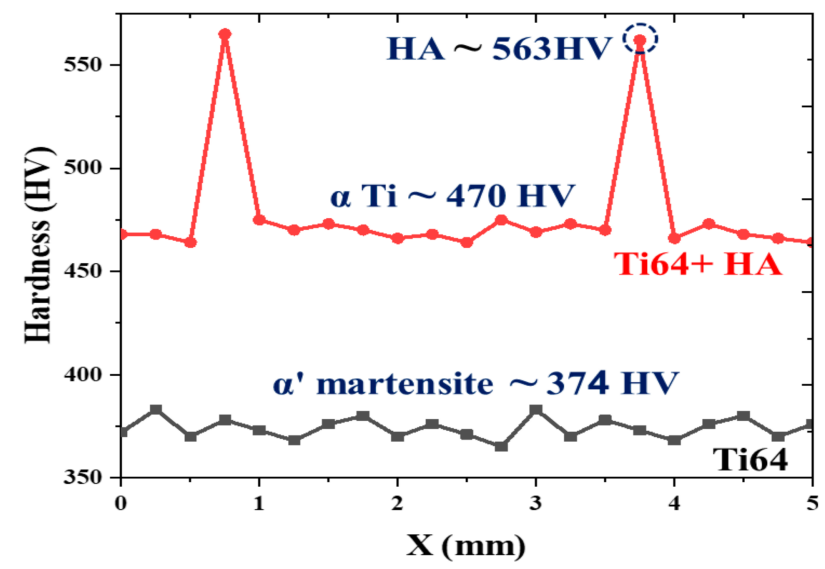

Figure 11. Corresponding microstructures are labelled on Vickers microhardness tests of the SLM Ti64 and Ti64-2\%HA composites.

Consequently, the microstructure of the SLM of Ti64-2\%HA composite was a complex mixture of $\alpha \mathrm{Ti}, \mathrm{HA}, \mathrm{Ti}_{3} \mathrm{P}, \mathrm{Ti}_{\mathrm{x}} \mathrm{O}, \mathrm{P}$, and $\mathrm{CaTiO}_{3}$. The average volume fraction of $\mathrm{HA}$ in the 
microstructure of the Ti64-Ha was approximately $10 \%$ based on Image J software. The formation of HA has been reported in the electron beam melting of Ti-HA composites [20]. It should be noted that the formation of $\mathrm{HA}$ and dispersed $\mathrm{Ca}, \mathrm{P}$, and $\mathrm{O}$ elements on the microstructure of implants may result in a higher tendency of good bone osseointegration and biocompatibility.

\subsection{Mechanical Properties}

To explore the mechanical properties of the Ti64 and Ti64-2\%HA, tensile and nanoindentation tests were performed. Figure 12 summarizes and compares the results of tensile tests on the SLM-processed Ti64-2\%HA composite with those of pure Ti64. The experimental results of the tensile test indicate that the addition of HA had a significant effect on the load carrying capacity of the selective laser melting. As depicted, adding $2 \mathrm{wt} . \%$ HA lowered yield strength, maximum tensile strength, and elongation of the selective laser melting from 1060, 1180, and 8 to 223, 255 and 0.9, respectively. The deterioration of tensile properties and improvement of hardness were due to the formation of brittle phases including $\mathrm{Ti}_{3} \mathrm{P}, \mathrm{CaTiO}_{3}$, and the precipitation of $\mathrm{HA}$ in grain boundaries. Moreover, adding $2 \mathrm{wt} . \%$ HA resulted in increases in the susceptibility of formation of pores and defects, leading to reduced tensile properties. Despite this, the tensile strength of the Ti64-2\%HA composite manufactured by SLM was approximately $2-3$ times higher than human bone. It has been reported that the tensile strength of human bones is between 60 and $130 \mathrm{MPa}[28,29]$. Figure 13 illustrates the typical load/nano-indentation depth curves for Ti64 and Ti64-2\%HA samples at a peak load of $3.5 \mathrm{mN}$. The indentation depth values of the Ti64 and Ti64-2\%HA samples were 580 and $450 \mathrm{~nm}$, respectively. According to Figure 13, the hardness of the Ti64-2\%HA was higher than the hardness of the Ti64. This was due to the formation of a hard and brittle structure in the Ti64-2\%HA sample as compared to the lath microstructure, consisting mainly of the $\alpha^{\prime}$ martensitic structure in the Ti64 sample.

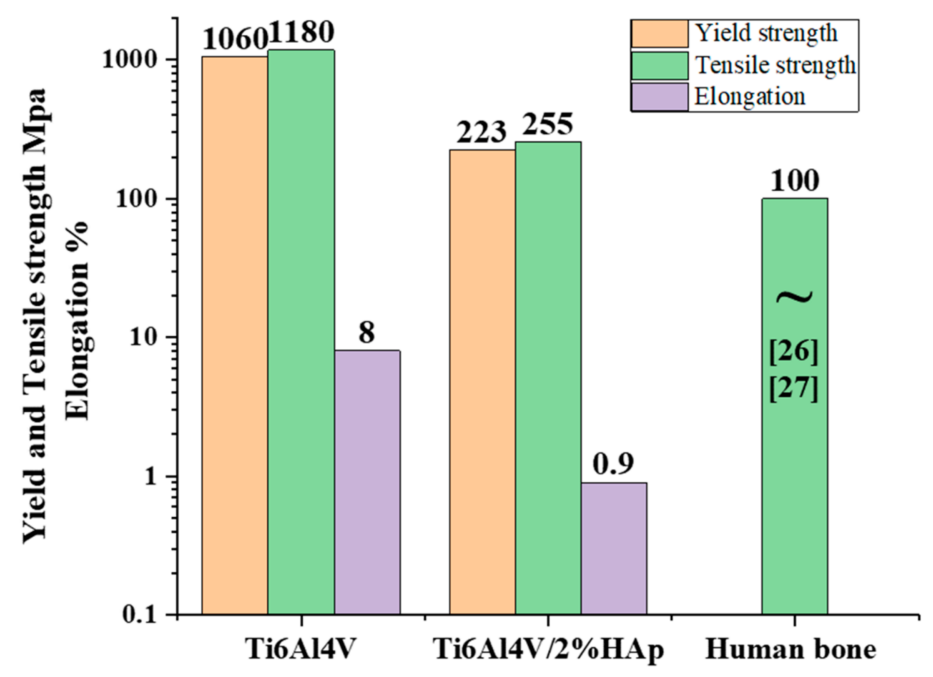

Figure 12. Tensile properties of the SLM Ti64 and Ti64-2\%HA composites. 


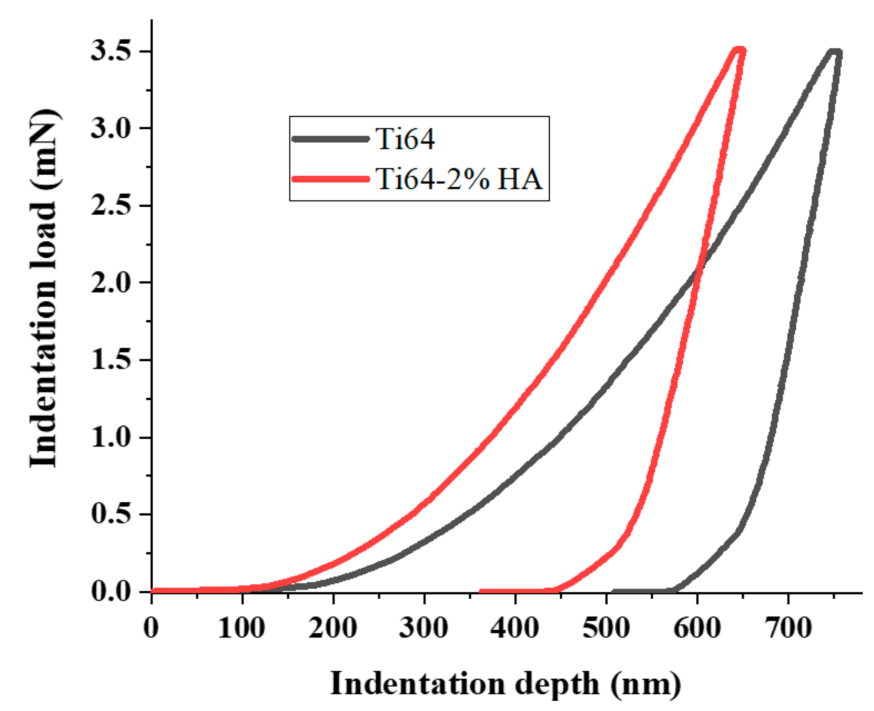

Figure 13. Load/nano-indentation depth curves of the SLM Ti64 and Ti64-2\%HA composites.

\section{Conclusions}

1. SLM of Ti64 components feature a lath microstructure, consisting mainly of $\alpha^{\prime}$ martensitic structure and a small amount of $\beta$-titanium $(\beta$-Ti) at grain boundaries;

2. SLM of Ti64-2\%HA composite components features small grains of $\alpha$ Ti coupled with dark grain boundaries of $\mathrm{HA}$ and some light green areas of $\mathrm{Ti}_{3} \mathrm{P}$, and other phases of $\mathrm{Ti}_{\mathrm{x}} \mathrm{O}, \mathrm{P}$, and $\mathrm{CaTiO}_{3}$;

3. The tensile properties of SLM Ti64-2\%HA composite components are significantly higher than human bone reported in the literature. Therefore, we recommend that further research should be undertaken in the SLM of compositionally/structures graded titanium-hydroxyapatite (functionally graded materials/structures) in order to mimic natural bone and provide good interfacial bonds between bone tissue and metallic implants;

4. For the same HA amount (2 wt.\%), decreasing energy density input led to lower tensile strength. Conversely, increasing energy density input has a negative effect on the manufacturing behavior because there were several explosions (popups) which led to a crash of the support structure. Therefore, it can be suggested that the preheated treatment of HA powder is required to remove the effect of this "gas/explosion" problem on the SLM-fabricated Ti64-2\%HA;

5. The SLM of Ti64-HA exhibited low tensile properties compared to the SLM of Ti64. This was attributed to the formation of brittle and hard HA in the grain boundary which promotes the growth of cracks.

Author Contributions: Investigation, H.J.; Methodology, H.J. and J.K.; Resources, H.J.; Supervision, T.A.K.; Writing—original draft, H.J.; Writing—review \& editing, T.A.K. All authors have read and agreed to the published version of the manuscript.

Funding: This work received no external funding.

Institutional Review Board Statement: Not applicable.

Informed Consent Statement: Not applicable.

Data Availability Statement: The data will be made available upon request.

Acknowledgments: The authors wish to thank Paulo Quadros (fluidinova.com), who provided us with hydroxyapatite and valuable advice in the early stages of this work. Additionally, we thank Z. Dankházi (ELTE TTK.hu) for his collaboration with scanning electron microscopy.

Conflicts of Interest: The authors declare no conflict of interest. 


\section{References}

1. Marchese, G.; Aversa, A.; Bassini, E. Microstructure and Hardness Evolution of Solution Annealed Inconel 625/TiC Composite Processed by Laser Powder Bed Fusion. Metals 2021, 11, 929. [CrossRef]

2. Jaber, H.; Kovacs, T.; János, K. Investigating the impact of a selective laser melting process on Ti6Al4V alloy hybrid powders with spherical and irregular shapes. Adv. Mater. Process. Technol. 2020, 1-17. [CrossRef]

3. Chioibasu, D.; Duta, L.; Popescu-Pelin, G.; Popa, N.; Milodin, N.; Iosub, S.; Balescu, L.M.; Galca, A.C.; Popa, A.C.; Oktar, F.N.; et al. Animal Origin Bioactive Hydroxyapatite Thin Films Synthesized by RF-Magnetron Sputtering on 3D Printed Cranial Implants. Metals 2019, 9, 1332. [CrossRef]

4. Jaber, H.; Kovacs, T.A. Selective laser melting of Ti alloys and hydroxyapatite for tissue engineering: Progress and challenges. Mater. Res. Express 2019, 6, 082003. [CrossRef]

5. Smallman, R.; Ngan, A. Case examination of biomaterials, sports materials and nanomaterials. In Physical Metallurgy and Advanced Materials Engineering; Elsevier: Amsterdam, The Netherlands, 2007; pp. 583-621.

6. Ke, D.; Vu, A.; Bandyopadhyay, A.; Bose, S. Compositionally graded doped hydroxyapatite coating on titanium using laser and plasma spray deposition for bone implants. Acta Biomater. 2019, 84, 414-423. [CrossRef]

7. Vasconcellos, L.M.R.; Oliveira, M.V.; Graça, M.L.A.; Vasconcellos, L.G.O.; Cairo, C.A.A.; Carvalho, Y.R. Design of dental implants, influence on the osteogenesis and fixation. J. Mater. Sci. Mater. Electron. 2008, 19, 2851-2857. [CrossRef] [PubMed]

8. Mullen, L.; Stamp, R.C.; Fox, P.; Jones, E.; Ngo, C.; Sutcliffe, C.J. Selective laser melting: A unit cell approach for the manufacture of porous, titanium, bone in-growth constructs, suitable for orthopedic applications. II. Randomized structures. J. Biomed. Mater. Res. Part B Appl. Biomater. 2009, 92, 178-188. [CrossRef]

9. Yousefi, A.-M. A review of calcium phosphate cements and acrylic bone cements as injectable materials for bone repair and implant fixation. J. Appl. Biomater. Funct. Mater. 2019, 17, 2280800019872594. [CrossRef]

10. Mohseni, E.; Zalnezhad, E.; Bushroa, A. Comparative investigation on the adhesion of hydroxyapatite coating on Ti-6Al-4V implant: A review paper. Int. J. Adhes. Adhes. 2014, 48, 238-257. [CrossRef]

11. Biemond, J.E.; Hannink, G.; Verdonschot, N.; Buma, P. Bone ingrowth potential of electron beam and selective laser melting produced trabecular-like implant surfaces with and without a biomimetic coating. J. Mater. Sci. Mater. Med. 2012, 24, 745-753. [CrossRef]

12. Vilotijevic, M.; Markovic, P.; Zec, S.; Marinkovic, S.; Jokanovic, V. Hydroxyapatite coatings prepared by a high power laminar plasma jet. J. Mater. Process. Technol. 2011, 211, 996-1004. [CrossRef]

13. Kaya, C.; Singh, I.; Boccaccini, A.R. Multi-walled Carbon Nanotube-Reinforced Hydroxyapatite Layers on Ti6Al4V Medical Implants by Electrophoretic Deposition (EPD). Adv. Eng. Mater. 2008, 10, 131-138. [CrossRef]

14. Peñarrieta-Juanito, G.; Sordi, M.B.; Henriques, B.; Dotto, M.E.R.; Teughels, W.; Silva, F.S.; Magini, R.S.; Souza, J.C.M. Surface damage of dental implant systems and ions release after exposure to fluoride and hydrogen peroxide. J. Periodontal Res. 2019, 54, 46-52. [CrossRef]

15. Jaber, H.L.; Hammood, A.S.; Parvin, N. Synthesis and characterization of hydroxyapatite powder from natural Camelus bone. J. Aust. Ceram. Soc. 2018, 54, 1-10. [CrossRef]

16. Han, C.; Wang, Q.; Song, B.; Li, W.; Wei, Q.; Wen, S.; Liu, J.; Shi, Y. Microstructure and property evolutions of titanium/nanohydroxyapatite composites in-situ prepared by selective laser melting. J. Mech. Behav. Biomed. Mater. 2017, 71, 85-94. [CrossRef]

17. Marcu, T.; Menapace, C.; Girardini, L.; Leordean, D.; Popa, C. Selective laser melting of Ti6Al7Nb with hydroxyapatite addition. Rapid Prototyp. J. 2014, 20, 301-310. [CrossRef]

18. Gu, Y.; Loh, N.; Khor, K.; Tor, S.; Cheang, P. Spark plasma sintering of hydroxyapatite powders. Biomaterials 2002, 23, 37-43. [CrossRef]

19. Nath, S.; Tripathi, R.; Basu, B. Understanding phase stability, microstructure development and biocompatibility in calcium phosphate-titania composites, synthesized from hydroxyapatite and titanium powder mix. Mater. Sci. Eng. C 2009, 29, 97-107. [CrossRef]

20. Terrazas, C.A.; Murr, L.E.; Bermudez, D.; Arrieta, E.; Roberson, D.A.; Wicker, R.B. Microstructure and mechanical properties of Ti-6Al-4V-5\% hydroxyapatite composite fabricated using electron beam powder bed fusion. J. Mater. Sci. Technol. 2019, 35, 309-321. [CrossRef]

21. ASM International. ASM Metals Handbook Volume 3 Alloy Phase Diagrams; ASM International: Materials Park, OH, USA, 1992; ISBN 0871703777.

22. Takeuchi, A.; Inoue, A. Classification of Bulk Metallic Glasses by Atomic Size Difference, Heat of Mixing and Period of Constituent Elements and Its Application to Characterization of the Main Alloying Element. Mater. Trans. 2005, 46, 2817-2829. [CrossRef]

23. Shishkovsky, I.V.; Tarasova, E.Y.; Petrov, A.L. The synthesis of a biocomposite based on nickel titanium and hydroxyapatite under selective laser sintering conditions. Tech. Phys. Lett. 2001, 27, 211-213. [CrossRef]

24. Shifeng, W.; Shuai, L.; Qingsong, W.; Yan, C.; Sheng, Z.; Yusheng, S. Effect of molten pool boundaries on the mechanical properties of selective laser melting parts. J. Mater. Process. Technol. 2014, 214, 2660-2667. [CrossRef]

25. Muhammad, M.; Pegues, J.W.; Shamsaei, N.; Haghshenas, M. Effect of heat treatments on microstructure/small-scale properties of additive manufactured Ti-6Al-4V. Int. J. Adv. Manuf. Technol. 2019, 103, 4161-4172. [CrossRef] 
26. Yan, X.; Yin, S.; Chen, C.; Huang, C.; Bolot, R.; Lupoi, R.; Kuang, M.; Ma, W.; Coddet, C.; Liao, H.; et al. Effect of heat treatment on the phase transformation and mechanical properties of Ti6Al4V fabricated by selective laser melting. J. Alloy. Compd. 2018, 764, 1056-1071. [CrossRef]

27. Murugan, R.; Ramakrishna, S. Development of nanocomposites for bone grafting. Compos. Sci. Technol. 2005, 65, 2385-2406. [CrossRef]

28. Wei, Q.; Li, S.; Han, C.; Li, W.; Cheng, L.; Hao, L.; Shi, Y. Selective laser melting of stainless-steel/nano-hydroxyapatite composites for medical applications: Microstructure, element distribution, crack and mechanical properties. J. Mater. Process. Technol. 2015, 222, 444-453. [CrossRef]

29. Kutz, M. Standard Handbook of Biomedical Engineering and Design, 1st ed.; McGraw-Hill Professional: New York, NY, USA, 2002; ISBN 0071356371. 